\title{
Electrophysiological changes during EMDR treatment in pateints with combat-related PTSD
}

\author{
Grozdanko Grbesa*, Maja Simonovic, Dorjanka Jankovic \\ From $1^{\text {st }}$ International Congress on Neurobiology and Clinical Psychopharmacology \\ and European Psychiatric Association Conference on Treatment Guidance \\ Thessaloniki, Greece. 19-22 November 2009
}

\section{Background}

Efficiency of the EMDR procedure is based on a presumption of neuropsychological changes in therapeutic process. The aim of the investigation is to scann and give evidence of electroactivity changes, during the process of EMDR procedure and after finishing it.

\section{Materials and methods}

We have recorded a continual polygraph EEG, before, during and after EMDR therapy, in patient with combat-related PTSD.

\section{Results}

Before the treatment, EEG recorded basic activity of low voltage (attenuation) of $20 \mu \mathrm{V}$, frequency of beta range (17-26 Hz), bioccipital, with no pathologic activity. Patient had prominent vegetative symptoms (anxiety, heart rate $100 / \mathrm{min}$ ). Background activity immediately after the treatment records the amplitude values of around $50 \mu \mathrm{V}$, frequency of around 11-12 Hz. After the end of the treatment background activity possesses the amplitude value of about $37 \mu \mathrm{V}$, holding the persistence in frequency.

\section{Conclusions}

If the EMDR treatment is successful, sudden increase of amplityde activity is noted imensly. This sharp border line, which signifies normal activity, appears in 2-3 seconds affter the desensitize phase. The investigation suggest that from neurophysiological point of view, cortex (in EMDR procedure), works according to the principle "all or nothing". If there is processing of traumatic memory, the activity gets completly normal. If the therapy is not successful, there are numerous artefacts,

Clinic for Mental Health, Clinical Centre, Nis, Serbia because of increased muscle activity. This kind of activity, in our investigation is marked as "Artefact therapy".

The results, indicate maintaining low level of amplitude values of electrocortical activities during the treatment, as well as increase after successful treatment. The increase of amlitude is corelated to decrease of anxiety after the successful treatment.

\section{Acknowledgements}

The results, indicate maintaining low level of amplitude values of electrocortical activities during the treatment, as well as increase after successful treatment. The increase of amlitude is corelated to decrease of anxiety after the successful treatment.

Published: 22 April 2010

\section{Reference}

1. EEG Asymmetry and its Clinical Correlates in PTSD, Steven Silverstein, Stewart Shankman. Lea Williams, Patrick Hopkinson, Richard Bryant.

\section{doi:10.1186/1744-859X-9-S1-S209}

Cite this article as: Grbesa et al:: Electrophysiological changes during EMDR treatment in pateints with combat-related PTSD. Annals of General Psychiatry 2010 9(Suppl 1):S209.
Submit your next manuscript to BioMed Central and take full advantage of:

- Convenient online submission

- Thorough peer review

- No space constraints or color figure charges

- Immediate publication on acceptance

- Inclusion in PubMed, CAS, Scopus and Google Scholar

- Research which is freely available for redistribution

Submit your manuscript at www.biomedcentral.com/submit
Biomed Central 